\title{
GAIA Level 2 Dysfunctional First Stage of Labor
}

National Cancer Institute

\section{Source}

National Cancer Institute. GAIA Level2 Dysfunctional First Stage of Labor. NCI

Thesaurus. Code C128718.

GAIA Level 2 Dysfunctional First Stage of Labor is defined by progress of less than $0.5 \mathrm{~cm}$ of cervical dilation per hour, for at least 4 hours, in women with established labor (i.e. have regular contractions and cervical dilation of at least $4 \mathrm{~cm}$ ) without certainty of ruptured membranes. 